\title{
Estimation of Kidney Dose for Pediatric Patients during X-Ray Examinations
} \author{
Salah A Fadlalla ${ }^{1}$ and Mohammed M Mustafa ${ }^{1}$ \\ ${ }^{1}$ Faculty of Diagnstic Radiology and Nuclear Medicine Sciences, the National Ribat University, Sudan \\ ${ }^{2}$ Collegeof Medical Radiologic science, Sudan University of Science and Technology, Khartoum, Sudan \\ ${ }^{3}$ Almoalem Medical City, Khartoum, Sudan
}

Nadia 0 Alatta ${ }^{1}$, Ahmed H Abdelrahim ${ }^{1}$, Ikhlas A Hassan*1,2, Mogahid MA Zidan ${ }^{1}$, Mohand Abdelalla ${ }^{3}$,

Received: April 28, 2018; Published: May 09, 2018

*Corresponding author: Ikhlas A Hassan, Faculty of Diagnstic Radiology and Nuclear Medicine Sciences, the National Ribat University, College of Medical Radiologic science, Sudan University of Science and Technology, Khartoum, Sudan

\begin{abstract}
This study was performed in three hospitals in Sudan to assess the values of entrance surface air kerma (ESAK) and kidneys' dose for 55 pediatric patients whom their ages arranged between 1 day-15years, underwent chest and abdominal radiographic examination. The essential aim of this study was to evaluate the value of kidneys' dose and compare the value of ESAK with the reference level for diagnostic. The CALDose_X software was used to estimate these values by entering the exposure factors Kv and mAs, the output of the machine and information about the patient age and gender. The dose of kidney variated from hospital to another in same exam, these variations due to difference in setting of exposure factors to each patient, also to the difference in the output of machine. By comparing these values with reference level for diagnostic, it was found that in some hospitals the values are higher than the reference level for diagnostic. Kidneys dose was small and it has considerable concern.
\end{abstract}

Keywords: Diagnostic Reference Level; Entrance Surface Dose; Chest x-ray; Abdoman x-ray; ESAK

\section{Introduction}

Diagnostic X-ray examinations play an important role in health care of the population in Sudan and worldwide. In X-ray diagnostics, radiation that is partly transmitted through and partly absorbed in the irradiated object is utilized. An X-ray image shows the variations in transmission caused by structures in the object of varying thickness, density or atomic composition [1]. It is important to remember that thousands of hospitals and medical institutions worldwide do not even have adequate resources to perform the most basic examinations safely, so the risk of radiation is increasing with increase the significant of diagnostic X-ray examinations and it can harm the human health by two ways: if the dose deposited above than tolerance (threshold) dose the effect is known as deterministic effect, and if the dose under the high dose it called stochastic effect [2]. The deposition of energy is characterized by radiation dose and the methods mentioned before are known as a biological effect. Understanding these interactions leads naturally to determination of radiation exposure and dose and the unit used to define them.

Biological effects of ionizing radiation are a consequence of the ionization of atoms of bimolecular, which might cause chemical changes and alter or eradicate its functions [3]. It depends on total energy of radiation absorbed per unit mass (in kg) of tissue or organ this quantity is called absorbed dose and expressed in Gray (Gy) [4]. If a patient is exposed to an X-ray beam, some of X-ray photons will pass through the patient without any interaction, and therefore will produce no biological effect. On the other hand X-ray photons which are absorbed may produce effects. Absorbed dose can be measured from basic evaluation of probability of radiation induced effect. In evaluating biological effects of radiation after a particular exposure of body. Radiation absorbed dose would be a suitable measure of biological injury, but this is not the case. Biological effects depend not only on the total energy deposited, but also on the way in which it is distributed along the path of the radiation [3]. The RisoCal Dose software is used to calculate the absorbed dose in Riso calorimeters based on resistance measurements before and after irradiation. This User Manual describes how to setup and use CalDose [5].

\section{Materials and Method}

\section{Material}

a) X-ray Machines information:The three hospitals are used different types of machine as in the below Table 1 . 
Table 1: The classification of patients according to the examinations and gender.

\begin{tabular}{|c|c|c|c|}
\hline Examination & Male & Female & Total \\
\hline Chest & 23 & 9 & 32 \\
\hline Abdominal & 14 & 9 & 23 \\
\hline
\end{tabular}

b) Patients: A total of 55 pediatric patients (37 male and 18 female)

c) CALDOSE Software program

d) RAD-CHECK

\section{Methods}

a) Method of Data Collection: Information "SSD, mAs, Age, gender, $\mathrm{kVp}$, and the output of the machine" were collected for 55 patient their ages between (1day-15year), with chest and abdominal radiographic examinations in three hospitals in Khartoum and Nyala state.

b) Method of Dose Measurement And Data Analyzed: RAD-CHECK was used to measure the radiation doses coming out of the x-ray tube machines corresponding different $\mathrm{kVp}$. CALDOSE determined organ doses and ESAK for each exam based on the mAs (tube current), FDD (field to detector distance), $\mathrm{kVp}$ (tube voltage), type of examination and the output of machine.Information was treated with CALDOSE software to calculate ESAK and organ doses, where the organ under study was the kidney.

\section{Data collection}

The study involved 55 patients their ages between (1day_15years), underwent chest and abdominal radiographic examination in three hospitals in Sudan A,B at Khartoum and C in Nyala. The data were collected using a sheet for all patients in order to maintain consistency of the information. The age, exposure factors and the type of examination were recorded.

\section{CALDose_X}

CALDose_X is a software tool that provides the possibility to calculate incident air kerma (INAK) and entrance surface air karmas (ESAK), two important quantities used in X-ray diagnosis, based on the output of the X-ray equipment. Additionally, the software uses conversion coefficients (CCs) to assess absorbed dose to organs and tissues of the human body, the effective dose as well as the patients' cancer risk for radiographic examinations. Various field positions, for 29 selected organs and tissues had been simultaneously calculated for the measurable quantities (INAK, ESAK, and kerma area product (KAP). Based on the X-ray irradiation parameters defined by the user, CALDose_X shows images of the phantom together with the position of the X-ray beam. By using true to nature voxel phantoms, CALDose_X improves earlier software tools, which were mostly based on mathematical phantoms. Poor representations of human anatomy. For the CALDose_X 5.0 to work, it is necessary to furnish the output in $\mathrm{mGy} / \mathrm{mAs}$, of all X-rays machines used in the evaluation of doses. Once the tube potential, the tube current, the exposure time, the
FDD, and focus-to-skin distance (FSD) were known, ESD could be calculated by The output is in $\mathrm{mGy} / \mathrm{mAs}$ of the X-ray tube at 80 $\mathrm{kv}$ at a distance $100 \mathrm{~cm}$ normalized to $10 \mathrm{mAs}$. BSF is backscatter factor for a particular examination at the required potential and was taken from NRPB numerical simulations. In order to determine the effective dose, CALDose_X5 provides separately calculated weighted and whole body absorbed doses, which represent the sex specific contributions to the effective dose. According to equation 4.5 in International Commission on Radiological Protection (ICRP) publication 103, the effective dose is then just the arithmetic mean of the two sex specific weighted absorbed doses [6].

\section{RAD-CHECK}

Rad Check Meter designed to measure Radioactive Contamination ( $\mathrm{RaC}$ ) in metals such as steel, brass, Aluminum, castings, other alloys and machined. This Portable Meter uses a sensitive scintillator with PMT as the detector. This meter gives optimum performance and measures very efficiently Low-Level Gamma Radiative Contamination $(\mathrm{RaC})$ in a variety of situations [7]. RAD-CHECK was used to measure the radiation doses coming out of the $\mathrm{x}$-ay tube machines corresponding different KVs in order to estimate the doses when data used in the software. The RADCHECK PLUS is a battery operated, portable unit which measures the output radiation of diagnostic x-ray equipment. The exposure is displayed on a $31 \backslash 2$ digit liquid crystal display (LCD) as either:

a) Exposure, in Roentgens (0.001 to $1.999 \mathrm{R}$ ) or SI units of milligrays (0.01 to $19.99 \mathrm{mGy}$ ).

b) Rate, in Roentgens per minute ( 0.01 to $19.99 \mathrm{R} / \mathrm{min}$ ) or $\mathrm{Si}$ units of milligrays per minute ( 0.1 to $199.9 \mathrm{mGy} / \mathrm{min}$ )

\section{Result}

The data has been collected from three hospitals at Khartoum state and Nyala in the department of radiology. The study involved 55 pediatric patients underwent chest and abdominal radiographic examination. Three different $\mathrm{x}$-ray machines in different radiology department at three hospitals were used as described in Table 1 Data were classified into three groups according to age, gender and examination described in the following Tables 2-6 RAD-CHECK was used to measure the radiation doses coming out of the X-ray tube machines corresponding different $\mathrm{KVp}$, the results are shown on the following tables arranged according to hospitals. After treating data with cal dose software the ESAK and kidneys dose were recorded. The percentage of kidneys dose, the average, maximum and minimum of all data group were determined. The result shown on the following tables arranged according to hospitals and age groups:(Tables 7-18).

Table 2: The classification of patients according to age and gender.

\begin{tabular}{|c|c|c|c|}
\hline Age & Male & Female & Total \\
\hline 1 day -5 years & 27 & 11 & 38 \\
\hline 5 years - 10 years & 5 & 2 & 7 \\
\hline 10 years - 15 years & 5 & 5 & 10 \\
\hline
\end{tabular}


Table 3: The output of the machine among different kilo voltage in hospital A.

\begin{tabular}{|c|c|c|c|}
\hline KVp & mAs & Distance (cm) & Reading \\
\hline 50 & 20 & 100 & 49.9 \\
\hline 60 & 20 & 100 & 58.9 \\
\hline 70 & 20 & 100 & 68.5 \\
\hline 80 & 20 & 100 & 78.03 \\
\hline 90 & 20 & 100 & 88.3 \\
\hline
\end{tabular}

Table 4: The output of the machine among different kilo voltage in hospital B.

\begin{tabular}{|c|c|c|c|}
\hline $\mathbf{K V p}$ & $\mathbf{m A s}$ & Distance $\mathbf{( c m )}$ & Reading \\
\hline 50 & 20 & 100 & 48.9 \\
\hline 60 & 20 & 100 & 59.6 \\
\hline 70 & 20 & 100 & 70.2 \\
\hline 80 & 20 & 100 & 79.0 \\
\hline 90 & 20 & 100 & 89.5 \\
\hline
\end{tabular}

Table 5: The output of the machine among different kilo voltage in hospital C.

\begin{tabular}{|c|c|c|c|}
\hline $\mathbf{K V p}$ & $\mathbf{m A s}$ & Distance $\mathbf{( c m )}$ & Reading \\
\hline 50 & 20 & 100 & 50.8 \\
\hline 60 & 20 & 100 & 60.7 \\
\hline 70 & 20 & 100 & 71.2 \\
\hline 80 & 20 & 100 & 81.6 \\
\hline 90 & 20 & 100 & 90.9 \\
\hline
\end{tabular}

Table 6: measured ESAK in hospital A during chest radiographic examination.

\begin{tabular}{|c|c|c|c|}
\multicolumn{1}{|c}{ Age } & \multicolumn{1}{c}{$\begin{array}{c}\text { Maximum } \\
\text { ESAK (mGy) }\end{array}$} & \multicolumn{1}{c|}{$\begin{array}{c}\text { Minimum } \\
\text { ESAK (mGy) }\end{array}$} & $\begin{array}{c}\text { Average } \\
\text { (mGy) }\end{array}$ \\
\hline 1 day - 5years & 1.306 & 0.126 & 0.716 \\
\hline 5 years - 10 years & 0.680 & 0.310 & 0.495 \\
\hline $\begin{array}{c}\text { 10 years - 15 } \\
\text { years }\end{array}$ & 0.663 & 0.389 & 0.526 \\
\hline
\end{tabular}

Table 7: measured kidneys dose in hospital A during chest radiographic examination.

\begin{tabular}{|c|c|c|c|c|c|c|}
\hline Age group & $\begin{array}{c}\text { Maximum kidneys } \\
\text { dose } \\
\text { (mGy) }\end{array}$ & $\begin{array}{c}\text { Minimum kidneys } \\
\text { dose } \\
\text { (mGy) }\end{array}$ & $\begin{array}{c}\text { Average } \\
\text { (mGy) }\end{array}$ & $\begin{array}{c}\text { Maximum kidneys dose } \\
\%\end{array}$ & $\begin{array}{c}\text { Minimum } \\
\text { kidneys dose } \\
\%\end{array}$ & $\begin{array}{c}\text { Average } \\
\%\end{array}$ \\
\hline 1 day - 5years & 0.0164 & 0.0011 & 0.0087 & 1.25 & 0.87 & 1.21 \\
\hline 5 years -10 years & 0.0079 & 0.0079 & 0.0079 & 1.16 & 2.54 & 1.59 \\
\hline 10 years -15 years & 0.0079 & 0.0072 & 0.0075 & 1.19 & 1.85 & 1.42 \\
\hline
\end{tabular}

Table 8: Measured ESAK in hospital A during abdominal radiographic examination.

\begin{tabular}{|c|c|c|c|}
\hline Age & Maximum ESAK (mGy) & Minimum ESAK (mGy) & Average (mGy) \\
\hline 1 day - 5years & 1.306 & 0.299 & 0.802 \\
\hline 5 years -10 years & 0.680 & 0.680 & 0.680 \\
\hline 10 years -15 years & 1.195 & 0.663 & 0.929 \\
\hline
\end{tabular}

Table 9: Measured kidneys dose in hospital A during abdominal radiographic examination.

\begin{tabular}{|c|c|c|c|c|c|c|}
\hline Age group & $\begin{array}{c}\text { Maximum } \\
\text { kidneys dose } \\
\text { (mGy) }\end{array}$ & $\begin{array}{c}\text { Minimum kidneys } \\
\text { dose } \\
\text { (mGy) }\end{array}$ & $\begin{array}{c}\text { Average } \\
\text { (mGy) }\end{array}$ & $\begin{array}{c}\text { Maximum } \\
\text { kidneys dose } \\
\text { \% }\end{array}$ & $\begin{array}{c}\text { Minimum kidneys } \\
\text { dose } \\
\%\end{array}$ & $\begin{array}{c}\text { Average } \\
\%\end{array}$ \\
\hline 1 day - 5years & 0.0164 & 0.0088 & 0.0126 & 1.25 & 2.94 & 1.57 \\
\hline 5 years - 10 years & 0.0132 & 0.0132 & 0.0132 & 1.94 & 1.94 & 1.94 \\
\hline 10 years - 15 years & 0.0135 & 0.0135 & 0.0135 & 1.13 & 2.04 & 1.45 \\
\hline
\end{tabular}

Table 10: Measured ESAK in hospital B during chest radiographic examination.

\begin{tabular}{|c|c|c|c|}
\hline Age & Maximum ESAK (mGy) & Minimum ESAK (mGy) & Average (mGy) \\
\hline 1 day - 5years & 1.252 & 0.233 & 0.742 \\
\hline 5 years -10 years & 0.310 & 0.310 & 0.310 \\
\hline 10 years - 15 years & 0.515 & 0.30 & 0.272 \\
\hline
\end{tabular}

Table 11: measured kidneys dose in hospital B during chest radiographic examination.

\begin{tabular}{|c|c|c|c|c|c|c|}
\hline Age group & $\begin{array}{c}\text { Maximum } \\
\text { kidneys dose }\end{array}$ & $\begin{array}{c}\text { Minimum kidneys } \\
\text { dose }\end{array}$ & Average & $\begin{array}{c}\text { Maximum } \\
\text { kidneys dose }\end{array}$ & $\begin{array}{c}\text { Minimum kidneys } \\
\text { dose }\end{array}$ & Average \\
\hline & (mGy) & (mGy) & (mGy) & $\%$ & $\%$ & $\%$ \\
\hline
\end{tabular}




\begin{tabular}{|c|l|l|l|l|l|l|}
\hline 1 day - yyears & 0.0161 & 0.0011 & 0.0086 & 1.28 & 0.47 & 2.16 \\
\hline 5 years -10 years & 0.0079 & 0.0079 & 0.0079 & 2.54 & 2.54 & 2.54 \\
\hline 10 years -15 years & 0.0079 & 0.0079 & 0.0079 & 1.53 & 2.63 & 2.90 \\
\hline
\end{tabular}

Table 12: Measured ESAK in hospital B during abdominal radiographic examination.

\begin{tabular}{|c|c|c|c|}
\hline Age & Maximum ESAK (mGy) & Minimum ESAK (mGy) & Average (mg) \\
\hline 1 day -5 years & 1.306 & 0.223 & 0.764 \\
\hline 5 years -10 years & 0.507 & 0.507 & 0.507 \\
\hline 10 years -15 years & - & - & - \\
\hline
\end{tabular}

Table 13: measured kidneys dose in hospital B during chest radiographic examination.

\begin{tabular}{|c|c|c|c|c|c|c|}
\hline Age group & $\begin{array}{c}\text { Maximum } \\
\text { kidneys dose } \\
\text { (mGy) }\end{array}$ & $\begin{array}{c}\text { Minimum kidneys } \\
\text { dose } \\
\text { (mGy) }\end{array}$ & $\begin{array}{c}\text { Average } \\
\text { (mGy) }\end{array}$ & $\begin{array}{c}\text { Maximum } \\
\text { kidneys dose } \\
\text { \% }\end{array}$ & $\begin{array}{c}\text { Minimum kidneys } \\
\text { dose } \\
\%\end{array}$ & $\begin{array}{c}\text { Average } \\
\%\end{array}$ \\
\hline 1 day - 5years & 0.0145 & 0.013 & 0.014 & 1.11 & 5.83 & 1.83 \\
\hline 5 years - 10 years & 0.0164 & 0.0164 & 0.0164 & 3.23 & 3.23 & 3.23 \\
\hline 10 years - 15 years & - & - & - & - & - \\
\hline
\end{tabular}

Table 14: Measured ESAK in hospital C during chest radiographic examination.

\begin{tabular}{|c|c|c|c|}
\hline Age & Maximum ESAK (mg) & Minimum ESAK (mg) & Average (mGy) \\
\hline 1 day - 5years & 1.316 & 0.311 & 0.813 \\
\hline 5 years -10 years & 0.388 & 0.312 & 0.350 \\
\hline 10 years -15 years & 0.389 & 0.310 & 0.349 \\
\hline
\end{tabular}

Table 15: Measured kidneys dose in hospital C during chest radiographic examination.

\begin{tabular}{|c|c|c|c|c|c|c|}
\hline Age group & $\begin{array}{c}\text { Maximum } \\
\text { kidneys dose } \\
\text { (mGy) }\end{array}$ & $\begin{array}{c}\text { Minimum kidneys } \\
\text { dose } \\
\text { (mGy) }\end{array}$ & $\begin{array}{c}\text { Average } \\
\text { (mGy) }\end{array}$ & $\begin{array}{c}\text { Maximum } \\
\text { kidneys dose } \\
\%\end{array}$ & $\begin{array}{c}\text { Minimum kidneys } \\
\text { dose } \\
\%\end{array}$ & $\begin{array}{c}\text { Average } \\
\%\end{array}$ \\
\hline 1 day - 5years & 0.0017 & 0.0011 & 0.0014 & 0.13 & 0.35 & 0.4 \\
\hline 5 years - 10 years & 0.0079 & 0.0079 & 0.0079 & 2.04 & 2.53 & 2.25 \\
\hline 10 years - 15 years & 0.0079 & 0.0077 & 0.0078 & 2.03 & 2.48 & 2.23 \\
\hline
\end{tabular}

Table 16: Measured ESAK in hospital C during abdominal radiographic examination.

\begin{tabular}{|c|c|c|c|}
\hline Age & Maximum ESAK (mGy) & Minimum ESAK (mGy) & Average (mGy) \\
\hline 1 day -5 years & 0.373 & 0.311 & 0.342 \\
\hline 5 years -10 years & - & - & - \\
\hline 10 years -15 years & 0.309 & 0.309 & 0.309 \\
\hline
\end{tabular}

Table 17: Measured kidneys dose in hospital C during abdominal radiographic examination.

\begin{tabular}{|c|c|c|c|c|c|c|}
\hline Age group & $\begin{array}{c}\text { Maximum } \\
\text { kidneys dose } \\
\text { (mGy) }\end{array}$ & $\begin{array}{c}\text { Minimum kidneys } \\
\text { dose } \\
\text { (mGy) }\end{array}$ & $\begin{array}{c}\text { Average } \\
\text { (mGy) }\end{array}$ & $\begin{array}{c}\text { Maximum } \\
\text { kidneys dose } \\
\%\end{array}$ & $\begin{array}{c}\text { Minimum kidneys } \\
\text { dose } \\
\%\end{array}$ & Average \\
$\%$
\end{tabular}

Table 18: Measured Comparison of average values at the three hospitals with local and international diagnostic reference level for chest and Abdomen examination [8,9].

\begin{tabular}{|c|c|c|c|}
\hline Exam & Present Study & D.R.L local & D.R.L international \\
\hline Chest & 0.360 & 0.66 & 0.40 \\
\hline Abdomen & 0.552 & 1.294 & 1.00 \\
\hline
\end{tabular}




\section{Discussion}

From results obtained, variations in the values of entrance surface air kerma ESAK and kidneys dose for 55 patients underwent chest and abdominal radiographic examination from one hospital to another were observe. As seen in the results of the patients their age between 1 day to 15 years. It is found that no regular quality control measurements were done to those hospitals. These variations were due to the difference in setup from one hospital to another for the same exam also due to the exposure factors used $[\mathrm{Kv}, \mathrm{mAs}$, field size], and also to difference in X-ray output from one hospital to another. To justify the differences, the effect of exposure factor and patient size and field size must be considered From (Tables 5,6,9,11,13 and 15).

a) Age group 1day-5years: The chest dose from hospital $\mathrm{C}$ is the highest and also doses received from three hospitals are higher than local and international diagnostic reference level, were as the abdomen dose is higher for hospital A and the dose received for the three hospitals are less than local and international reference level.

b) Age group 5years-10years: The chest dose from hospital A is the higher than international reference level while the others are smaller than local and international diagnostic reference level, were as the abdomen dose is smaller for hospital B and the dose received for the three hospitals are less than local and international diagnostic reference level.

c) Age group 10years - 15years: The chest dose from hospital $\mathrm{B}$ is the smallest at all but the dose received from hospital $\mathrm{A}$ is higher than international diagnostic reference level, not only the abdomen dose smaller for hospital $\mathrm{C}$ and the dose received for the three hospitals are less than local and international diagnostic reference level.From Tables $(6,8,10$, 12, 14 and 16):

d) Age group 1day - 5years: The chest dose from hospital C is the smallest than local and international diagnostic reference level and also dose received from three hospitals are lowest than local and international diagnostic reference level, were as the abdomen dose is the smaller for hospital $\mathrm{C}$ and the dose received for the three hospitals are less than local and international diagnostic reference level.

e) Age group 5years - 10years: Chest dose for the three hospitals are equal and smaller than local and international diagnostic reference level, were as the abdomen dose is smaller for hospital A\&B than local and international diagnostic reference level.

f) Age group 10years - 15years: Chest dose for the three hospitals are approximately equal, in addition to they are smaller than local and international reference level, were as the abdomen dose for hospital $\mathrm{C}$ is the smallest than local and international diagnostic reference level.In Table 17 the variation in values of entrance surface air kerma ESAK from one hospital to another during chest radiographic examination were observed. Also in hospitals the dose approximately equal the international diagnostic reference level, but it has small difference with local diagnostic reference level [8].

From Table 18the variation in values of entrance surface air kerma ESAK from one hospital to another during abdominal radiographic examination were observed. In addition it seems to be half of international diagnostic reference level and less by three times with local diagnostic reference level [9]. RAD-CHECK was used to measure the radiation doses coming out of the x-ray tube machines corresponding different KV [7]. Patients underwent abdominal radiographic examination have higher entrance surface air kerma than patient underwent chest radiographic examination. The difference between male and female for ESAK is not far during chest and abdominal radiographic examination.

\section{Conclusion}

In this study ESAK and kidneys dose were assessed for 55 pediatric patients underwent chest and abdominal radiographic examination in three hospitals.From the result and discussion stated above a lot of work should be done to narrow the gap between the values of ESAK and kidney's dose to the same exam in each hospital. Differences were observed between the values of ESAK and kidney's dose in each hospital for different examinations; these differences were due to differences in setup, exposure factors to the same exam in each hospital and the output of the machine. Comparisons of doses received during the study and the reference values were shown.

\section{References}

1. Nadine Barrie Smith (2011) Introduction to Medical Imaging Physics, Engineering and Clinical Applications Pennsylvania State University, USA.

2. (2016) World Health Organization, Communicating radiation risks in pediatric imaging: information to support health care discussions about benefit and risk.

3. (2013) Canadian Association of Radiologist, Medical Imaging Primer with a Focus on X- ray Usage and Safety.

4. (2014)Radiation Protection and Safety of Radiation Sources: International Basic Safety Standard.

5. James Bjorken Etal (1995) Periodical of particle physics, Rene Donaldson - Bill Kirk, Summer.

6. James R (2005) Connolly, for EPS400-002, Introduction to X-Ray Powder Diffraction, Spring.

7. (2005) Radiation Management Services Nuclear Associates USA - RADCHECK $^{\text {TM }}$ PLUS March 2005 Manual No.136201Rev.

8. NO Alatts (2014) Radiation doses from chest X-ray examinations for pediatrics in some hospitals of Khartoum State. Sudan 8: 186-188.

9. NO Alatts (2014) Diagnostic Reference Levels of Radiation Dose for Pediatric Patients in Khartoum State Hospitals. 


\section{(C) (i) This work is licensed under Creative}

Submission Link: https://biomedres.us/submit-manuscript.php

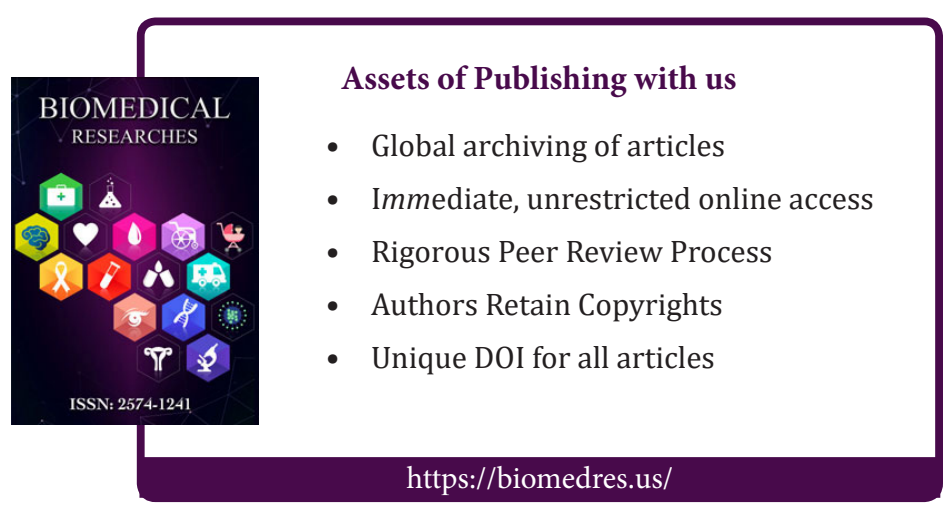

